\title{
Morphological features of the leaves in clematises as a reflection of their ecological peculiarities
}

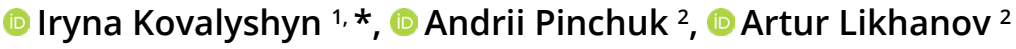 \\ 1 Institute of Plant Physiology and Genetics, National Academy of Science of Ukraine, Vasylkivska str. 31/17, 03022 Kyiv, Ukraine; \\ * Iryna_B_Kovalyshyn@ukr.net \\ ${ }^{2}$ National University of Life and Environmental Sciences of Ukraine, Heroyiv Oborony str. 15, 03041 Kyiv, Ukraine
}

Received: 13.01.2021 | Accepted: 01.06.2021 | Published online: 14.06.2021

\begin{abstract}
Quantitative morpho-anatomical features of leaves of nine Clematis taxa (C. alpina 'Pamela Jackman', C. macropetala 'Maidwell Hall', C. integrifolia 'Aljonushka', C. ispahanica 'Zvezdograd', C. fargesii 'Paul Farges', C. texensis 'Princess Diana', C. tibetana, C. viticella, and C. heracleifolia) were determined with the aim to analyze their adaptation to the environmental conditions.

Among investigated clematises, there were plants with hypostomatic (C. viticella, C. fargesii 'Paul Farges', C. heracleifolia, C. texensis 'Princess Diana', C. macropetala 'Maidwell Hall', and C. alpina 'Pamela Jackman'), and amphistomatic leaves (C. ispahanica 'Zvezdograd' and C. tibetana). In C. integrifolia 'Aljonushka' leaves were hypostomatic, but few solitary stomata were also present on the adaxial surface. In the leaves of investigated taxa, the palisade coefficient ranged from $27.3 \%$ (C. alpina 'Pamela Jackman') to $49.9 \%$ (C. tibetana). The leaves also differed significantly in size. In particular, leaves of C. integrifolia 'Aljonushka' were almost ten times smaller than such of $C$. heracleifolia.

As a result of UPGMA clustering, the plants that can survive in severe windy weather in open rocky areas, Clematis tibetana and C. ispahanica 'Zvezdograd', were joined in a separate cluster. The second cluster combined C. alpina 'Pamela Jackman' and C. macropetala 'Maidwell Hall' - cultivars blooming in the spring, during a period of significant difference in daily temperatures. A relatively small leaf area in plants from these two clusters may indicate an adaptation by reducing the transpiration area and general windage. The third cluster united the rest of investigated taxa, mostly - the mesophytic plants with a relatively large leaf area. However, due to similar morpho-anatomical structure of the leaf, the third cluster also comprised C. integrifolia 'Aljonushka' with the smallest leaves.
\end{abstract}

Keywords: Clematis, cluster analysis, leaf, epidermis, mesophyll

Authors' contributions: Iryna Kovalyshyn collected and contributed data, performed the analysis, wrote the paper. Andrii Pinchuk conceived and designed the analysis, wrote the paper. Artur Likhanov conceived and designed the analysis, performed the analysis.

Funding: The research was carried out at the expense of state funding.

Competing Interests: The authors declare no conflict of interest.

\section{Introduction}

The genus Clematis L. (Ranunculaceae Juss.) unites valuable ornamental and medicinal plants of various life forms, which grow on all continents except Antarctica (Sneddon, 1975; Takhtajan, 1978; Tamura, 1993; Moon et al., 2013; Zhang et al., 2013). Due to the 
Table 1. Investigated Clematis taxa and their natural ranges following Beskaravaynaya (1998) and Clematis on the Web (2021).

\begin{tabular}{|c|c|c|}
\hline Taxon & Breeding technology & Natural range \\
\hline $\begin{array}{l}\text { C. alpina (L.) Mill, } \\
\text { 'Pamela Jackman' }\end{array}$ & $\begin{array}{l}\text { Selection from C. alpina seed } \\
\text { offsprings }\end{array}$ & $\begin{array}{l}\text { Forests in the mountains of Central and Eastern } \\
\text { Europe (rocky slopes, river banks and bushes) }\end{array}$ \\
\hline $\begin{array}{l}\text { C. macropetala Ladeb. } \\
\text { 'Maidwell Hall' }\end{array}$ & $\begin{array}{l}\text { Selection from C. macropetala seed } \\
\text { offsprings }\end{array}$ & $\begin{array}{l}\text { Open shaded slopes, edges, coniferous and } \\
\text { deciduous forests of Eastern Siberia, the Far East, } \\
\text { China, North Korea, and Eastern Mongolia }\end{array}$ \\
\hline $\begin{array}{l}\text { C. integrifolia L. } \\
\text { 'Aljonushka' }\end{array}$ & $\begin{array}{l}\text { Hybridization C. jackmanii } \\
\text { 'Nezhdannyi' } \times \text { C. integrifolia }\end{array}$ & $\begin{array}{l}\text { Clematis integrifolia is common among shrubs, } \\
\text { on the edges and banks of rivers of Crimea, } \\
\text { Prykarpattia, Western Europe, the Caucasus, } \\
\text { Northern Kazakhstan, Turkey, Western China. } \\
\text { Clematis jackmanii 'Nezhdannyi was obtained by } \\
\text { free pollination of C. jackmanii }\end{array}$ \\
\hline $\begin{array}{l}\text { C. ispahanica Boiss. } \\
\text { 'Zvezdograd' }\end{array}$ & Mutagenesis of C. ispahanica & $\begin{array}{l}\text { Clematis ispahanica grows on steppe slopes in } \\
\text { Central Asia and Iran }\end{array}$ \\
\hline $\begin{array}{l}\text { C. fargesii Franch. } \\
\text { 'Paul Farges' }\end{array}$ & $\begin{array}{l}\text { Hybridization C. fargesii × } \\
\text { C. vitalba L. }\end{array}$ & $\begin{array}{l}\text { Clematis fargesii grows in West China. Clematis } \\
\text { vitalba occurs in Crimea, Caucasus, Central and } \\
\text { Southern Europe, Asia Minor, and North Africa }\end{array}$ \\
\hline $\begin{array}{l}\text { C. texensis Buckl. } \\
\text { 'Princess Diana' }\end{array}$ & $\begin{array}{l}\text { Hybridization Clematis 'Bees' Jubilee' } \\
\times \text { C. texensis }\end{array}$ & $\begin{array}{l}\text { Clematis texensis grows in USA (Texas). Origin of } \\
\text { Clematis 'Bees' Jubilee' is unknown }\end{array}$ \\
\hline C. tibetana Kuntze & & $\begin{array}{l}\text { Southeast Asia (Indian Himalayas, Nepal, China, and } \\
\text { Tibet) }\end{array}$ \\
\hline C. viticella $\mathrm{L}$. & & $\begin{array}{l}\text { Rocky slopes and edges in Southern Europe, } \\
\text { Western Caucasus, Iran, Asia Minor }\end{array}$ \\
\hline C. heracleifolia DC. & & East China and Korea \\
\hline
\end{tabular}

long history of introduction and selection, many clematises are available for planting in a moderate climatic zone and are successfully cultivated in Ukrainian botanical gardens (Rijekstynja \& Rijekstynysh, 1990; Tamura, 1993; Vachnovskaya, 2007). Taking into account the wide range of decorative application, clematises are good plants for urban gardening.

Clematises differ in the rhythms of their development and can be deciduous or evergreen. They are mainly entomophilous, monoecious or dioecious plants with opposite pinnate leaves. Morpho-anatomical diversity of their leaves is often determined by the ecological conditions of their habitats (they often occupy forest edges, rocky slopes, rocky river banks, and also steppes and desert landscapes) in different climatic zones (Rijekstynja \& Rijekstynysh, 1990; Tamura, 1993; Buisson \& Lee, 1993; Bååth \& Anderson, 2003; Ahmad et al., 2016; Arimy et al., 2017).

Adaptation to environmental conditions is reflected in the size, orientation, and density of structural elements of the leaf (Pashkevych, 2014; Arimy et al., 2017; Zanão Júnior et al., 2017; Araujo et al., 2019; Ornellas et al., 2019). The mechanisms of such adaptation may differ (e.g., by changing the area and thickness of the leaf blade, mesophyll or epidermal cell sizes, number of stomata, or developing the pubescence), but some genetically determined traits remain intact (e.g., the type of leaf blade, vascularization, stomatal apparatus, and trichomes). Therefore, the anatomical structure of the leaves often serves as a valuable source of taxonomic features (Isnard et al., 2003; Jinghua \& Liangqian, 2003; Javed et al., 2012). Taking into account these two aspects, we analyzed morpho-anatomical features of the leaves of nine Clematis taxa to evaluate their adaptive potential to urban conditions.

\section{Material and methods}

Morphological peculiarities were analyzed for nine Clematis taxa (Table 1), which were 
chosen due to their high ornamental features combined with the possibility of growing in public urban plantations. Selected plants vary phenologically and morphologically, so they can be applied for the creation of specific landscape compositions. They also differ by origin, which causes some ecological preferences and peculiarities.

For the morphological analysis, for each taxon five mature leaves of the brunch middle part were selected from the western side of plant habitus. Middle parts of leaflets from selected leaves were used for cuts and preparation of the permanent slides. Imprints of abaxial and adaxial sides of mature leaves were applied to determine the structure of the epidermis (Evert, 2005). The anatomical structure of the leaves was studied using permanent $(10 \mu \mathrm{m}$ thick) and native slides. Differentiated staining of the leaf tissues was performed using safranin (stains lignified elements) and water blue (stains unlignified elements) dyes (Furst, 1979).

The palisade coefficient indicates the percentage of palisade mesophyll layer from total mesophyll layer in the leaf blade and was calculated by the formula:

$$
\mathrm{K}=100 * \mathrm{M}_{\mathrm{P}} / \mathrm{M}_{\mathrm{P}+\mathrm{S}} \text {, where }
$$

$\mathrm{K}$ - the palisade coefficient, in \%,

$\mathrm{M}_{\mathrm{P}}$ - the height of the palisade mesophyll cells layer on the cross-section of the leaf, in $\mu \mathrm{m}$ $\mu \mathrm{m}$.

$\mathrm{M}_{\mathrm{P}+\mathrm{S}}$ - the total height of the mesophyll, in

Following leaf characters were analysed: 1 - leaf blade thickness, $\mu \mathrm{m} ; 2$ - height of the upper epidermis cells, $\mu \mathrm{m} ; 3$ - width of upper epidermis cell, $\mu \mathrm{m} ; 4$ - height of lower epidermis cells, $\mu \mathrm{m} ; 5$ - width of lower epidermis cells, $\mu \mathrm{m} ; 6$ - thickness of palisade mesophyll layer, $\mu \mathrm{m} ; 7$ - height of palisade mesophyll cell, $\mu \mathrm{m} ; 8$ - width of palisade mesophyll cell, $\mu \mathrm{m} ; 9$ - thickness of spongy mesophyll, $\mu \mathrm{m} ; 10$ - height of spongy mesophyll cells, $\mu \mathrm{m}$; 11 - width of spongy mesophyll cells, $\mu \mathrm{m} ; 12$ - diameter of vascular bundle with sheath cells, $\mu \mathrm{m} ; 13$ - diameter of vascular bundle (transverse), $\mu \mathrm{m} ; 14$ - diameter of vascular bundle (longitudinal), $\mu \mathrm{m}$; 15 - diameter of xylem vessels (transverse), $\mu \mathrm{m}$; 16 - diameter of xylem vessels (longitudinal), $\mu \mathrm{m} ; 17$ - height of phloem, $\mu \mathrm{m} ; 18$ - diameter of bundle sheath cells, $\mu \mathrm{m} ; 19$ - thickness of xylem vessels walls, $\mu \mathrm{m} ; 20$ - thickness of upper epidermis cells outer walls, $\mu \mathrm{m}$; 21 - thickness of lower epidermis cells outer walls, $\mu \mathrm{m} ; 22$ - thickness of upper epidermis cuticle, $\mu \mathrm{m} ; 23$ - thickness of lower epidermis cuticle, $\mu \mathrm{m} ; 24$ - width of stomata on the abaxial surface, $\mu \mathrm{m} ; 25$ - width of stomata on the adaxial surface, $\mu \mathrm{m} ; 26$ - length of stomata on the abaxial surface, $\mu \mathrm{m} ; 27$ - length of stomata on the adaxial surface, $\mu \mathrm{m} ; 28$ - leaf area, $\mathrm{dm}^{2} ; 29$ - leaf perimeter, dm; 30 - leaf mass of defined area, $\mathrm{g} / \mathrm{dm}^{2} ; 31$ - leaf mass of a defined volume, $\mathrm{g} / \mathrm{cm}^{3} ; 32$ - number of stomata on the abaxial leaf surface, pcs. $/ \mathrm{mm}^{2}$; 33 - number of stomata on the adaxial leaf surface, pcs. $/ \mathrm{mm}^{2} ; 34$ - number of ordinary epidermal cells on the abaxial leaf surface, pcs. $/ \mathrm{mm}^{2} ; 35$ - number of ordinary epidermal cells on the adaxial leaf surface, pcs. $/ \mathrm{mm}^{2}$; 36 - stomatal index of leaf abaxial surface \%; 37 - stomatal index of leaf adaxial surface, \%. Vascular bundles have elliptical form, and therefore their size and form description suspect definition of two mutually perpendicular diameters: longitudinal (the longest one) and transverse (the shortest one), which we used for our analysis.

Cluster analysis was performed using UPGMA method. UPGMA is effective when objects actually form different "groves"; however, it works equally well in cases of extended (chain type) clusters (Systat Software, 2010; Addinsoft, 2017). Simultaneously, Principle Component Analysis (PCA) was applied as one of the most frequently used multivariate data analysis methods suitable for our purposes (Addinsoft, 2017).

The anatomical structure of the leaves was investigated using a microscope Nikon Eclipse E-200 (Japan). Measurements of linear dimensions and areas were performed using Image-Pro Premier 9.1 software. Statistica 6.0 and SigmaPlot softwares were used for the statistical processing of obtained data (Box et al., 2005; Systat Software, 2010; Everitt et al., 2011).

\section{Results and discussion}

Ecological conditions of the habitat influence affect morphology and anatomy of plants in 
different ways. In case of studied clematises, altitude and insolation play principal role. The common feature of high-altitudinal plants is relatively thick leaf blades (Kogami et al., 2001; Zarinkamar et al., 2011; Ahmad et al., 2016; Arimy et al., 2017). It was also found that such plants, if compare with the plants from lower altitudes, have lower stomata density (Zarinkamar et al., 2011; Arimy et al., 2017), intensive sclerification around the vascular bundles (Ahmad et al., 2016), thick walls of epidermal cells, and, usually, amphistomatic leaves (Ornellas et al., 2019). From the other hand, in case of sufficient insolation, neutral and filtered shades cause the decrease of leaf thickness and area, leaf weight, stomatal density, palisade cell length, mesophyll thickness, and increase in chlorophyll content, degree of air spaces, adaxial width of palisade cell, and perimeter to area ratio (Buisson \& Lee, 1993; Hanba et al., 2002).

Leaves of studied clematises were imparipinnate petiolate, with leaflets having tripartite (except $C$. heracleifolia, which preserves the triple structure of leaves), toothed (C. alpina 'Pamela Jackman', C. macropetala 'Maidwell Hall', C. ispahanica 'Zvezdograd', C fargesii 'Paul Farges', C. tibetana, and C. heracleifolia) or entire (C. integrifolia 'Aljonushka', C. taxensis 'Princess Diana', and C. viticella) outlines of their margins. The leaf tip was always pointed. The leaf bases varied from wedge-shaped to notched (Fig. 1). Additionally, climbing clematises had modified petioles-tendrils for attachment to the vertical surfaces.

In general, the leaves of the studied plants differed significantly in shape and area (Fig. 2). The leaf surface area of the studied plants ranged from $1838 \mathrm{~mm}^{2}$ in C. integrifolia 'Aljonushka' to $18095 \mathrm{~mm}^{2}$ in C. heracleifolia.

The leaf blades of the studied clematises demonstrated dorsoventral structure. There were plants with hypostomatic (C. viticella, C. fargesii 'Paul Farges', C. heracleifolia, C. texensis 'Princess Diana', C. macropetala 'Maidwell Hall', and C. alpina 'Pamela Jackman') and amphistomatic leaves (C. ispahanica 'Zvezdograd' and C. tibetana). In C. integrifolia 'Aljonushka', beside the numerous stomata on the abaxial surface of the leaves, there were also observed solitary stomata on their adaxial side. In all studied plants, the stomata of the anomocytic type were found. The maximal stomatal area (C. macropetala 'Maidwell Hall') almost twice exceeded the minimal discovered one (C. texensis 'Princess Diana'). Ordinary epidermal cells varied in shape and size and differed between the experimental plants and even within the leaf surfaces of the same taxon. The height of mesophyll and the ratio of palisade and spongy layers differed among studied plants too (Fig. 3).

The minimal value of the palisade coefficient was found in the leaves of C. alpina 'Pamela Jackman' $(27.3 \%)$. For the rest plants, it was within the range of $30-40 \%$ (C. macropetala 'Maidwell Hall', C. integrifolia 'Aljonushka', C. fargesii 'Paul Farges', C. texensis 'Princess Diana', and C. heracleifolia) or 40-50\% (C. viticella, C. ispahanica 'Zvezdograd', and C. tibetana).

Palisade mesophyll was represented by two layers of cells in C. ispahanica 'Zvezdograd', C. integrifolia 'Aljonushka', and C. tibetana, and by a single layer in other studied taxa. Loose spongy mesophyll with large intercellular spaces was found in C. texensis 'Princess Diana', C. heracleifolia, C. fargesii 'Paul Farges', and C. tibetana. In other studied plants, spongy mesophyll was denser with clear boundaries between the layers. In $C$. integrifolia 'Aljonushka' it consisted of three or four cell layers, while in C. viticella and C. alpina 'Pamela Jackman' - of three layers (Fig. 4).

Leaf morphological and anatomical features were analysed by PCA. We used nine clematis taxa as observations and 37 characters and indexes of the leaf blade as variables (Fig. 5). From the list of investigated characters, we selected 22 variables, which made the most substantial contribution to PCA dispersion. Selected features in complex allowed comparing light intensity preferences and drought-resistance of plants and their ability to accumulate and retain water (Table 2).

The PCA showed that $C$. texensis 'Princess Diana' differs from other studied plants by the thickness of outer cell walls of upper epidermis, while C. macropetala 'Maidwell Hall' differs by the size of cells of spongy mesophyll and lower epidermis. Clematises with largest (C. heracleifolia and C. fargesii 'Paul Farges') and smallest leaves (C. integrifolia 'Aljonushka'), sure thing, strongly differed from other studied plants by the leaf area. Besides this, C. integrifolia 'Aljonushka' and C. fargesii 'Paul Farges' differed by a high 
A

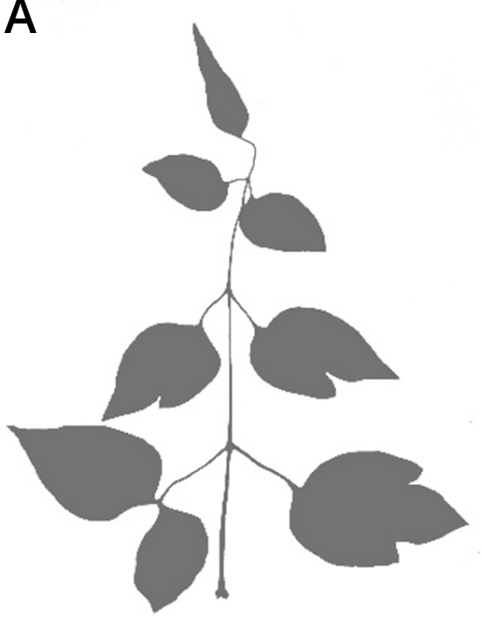

D

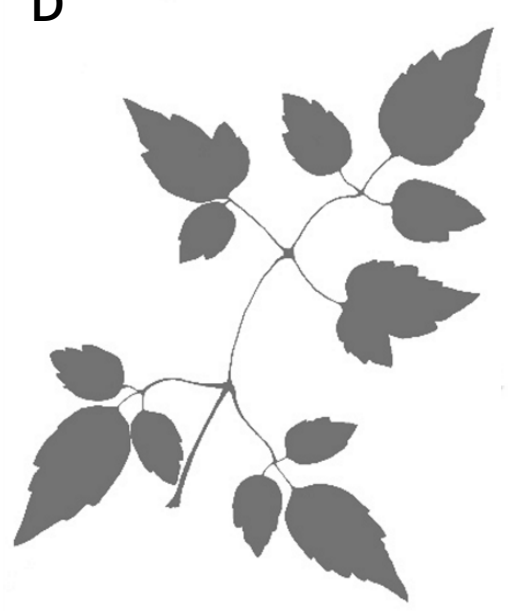

G

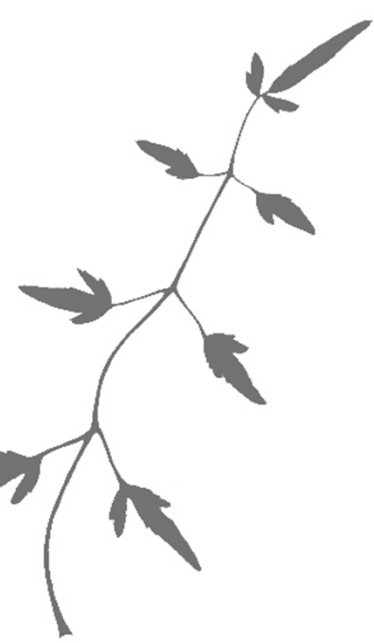

B

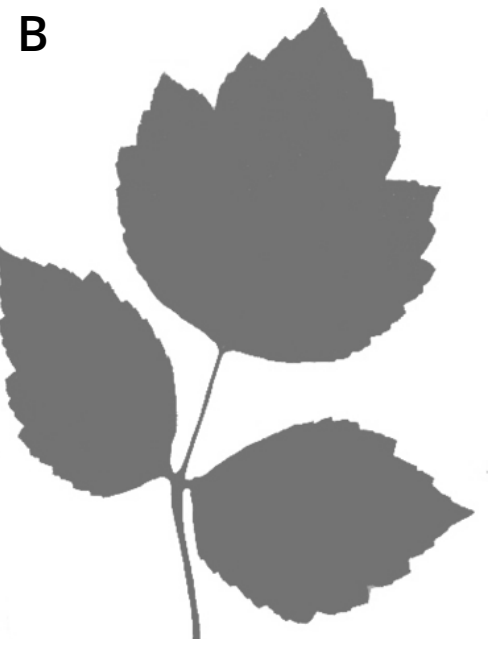

$\mathrm{E}$

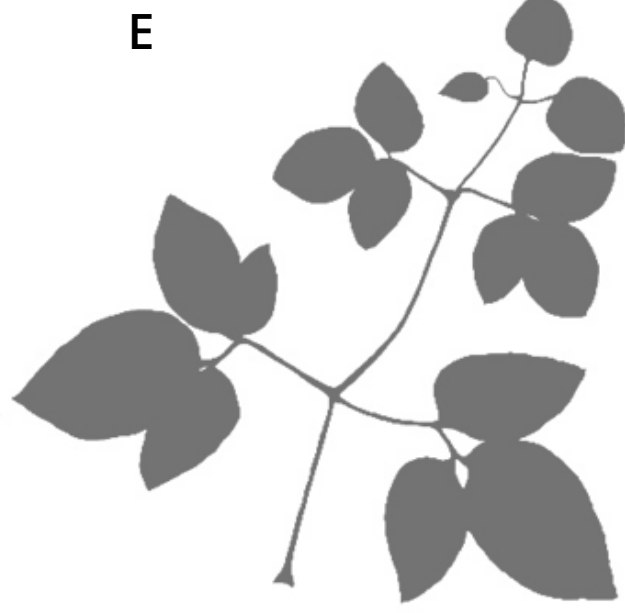

$\mathrm{H}$

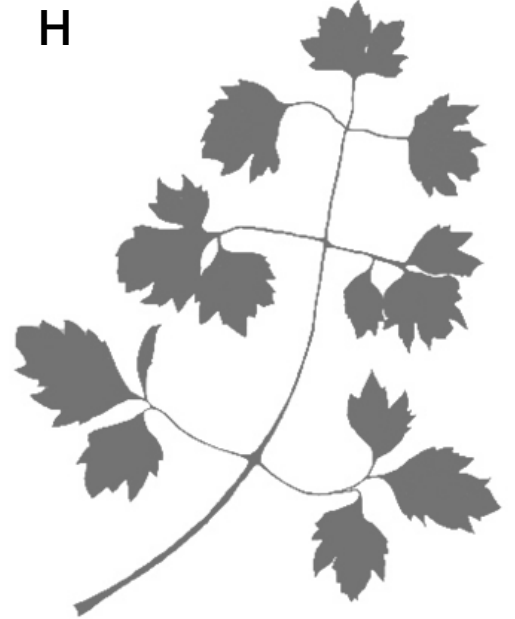

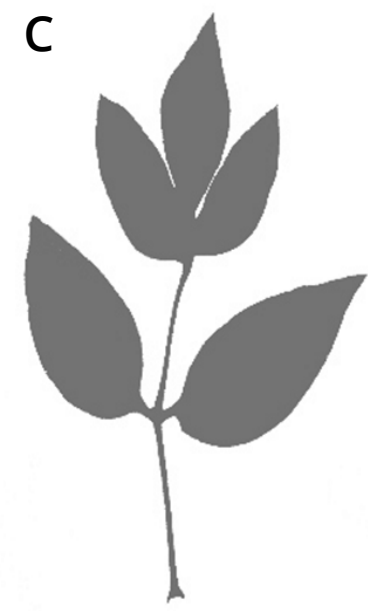

$\mathbf{F}$
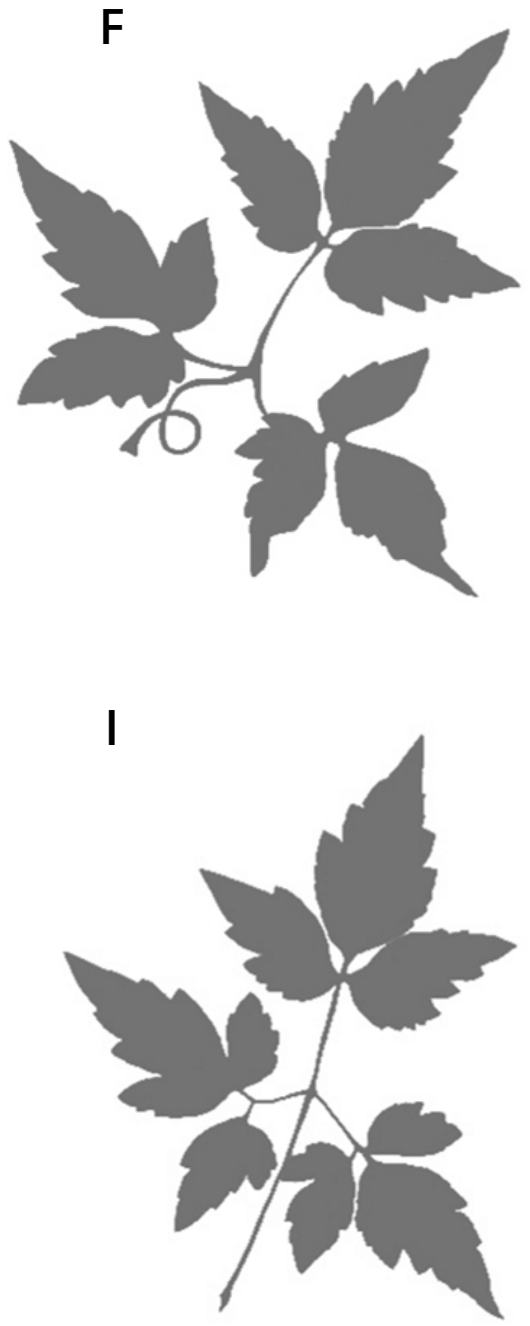

Figure 1. Outlines of Clematis leaves: A - C. texensis 'Princess Diana'; B - C. heracleifolia; C - C. integrifolia 'Aljonushka'; D - C. fargesii 'Paul Farges'; E - C. viticella; F - C. alpina 'Pamela Jackman'; G - C. ispahanica 'Zvezdograd'; H - C. tibetana; I - C. macropetala 'Maidwell Hall'. 


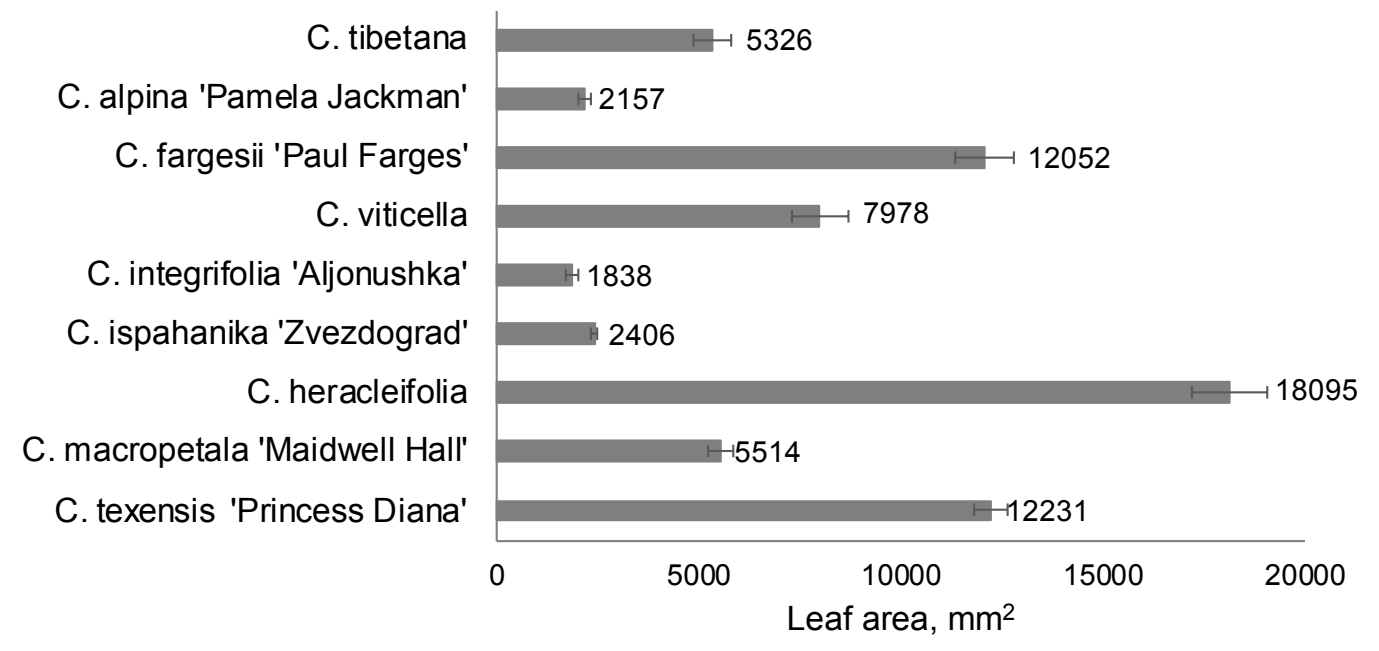

Figure 2. The leaf area of studied clematises.

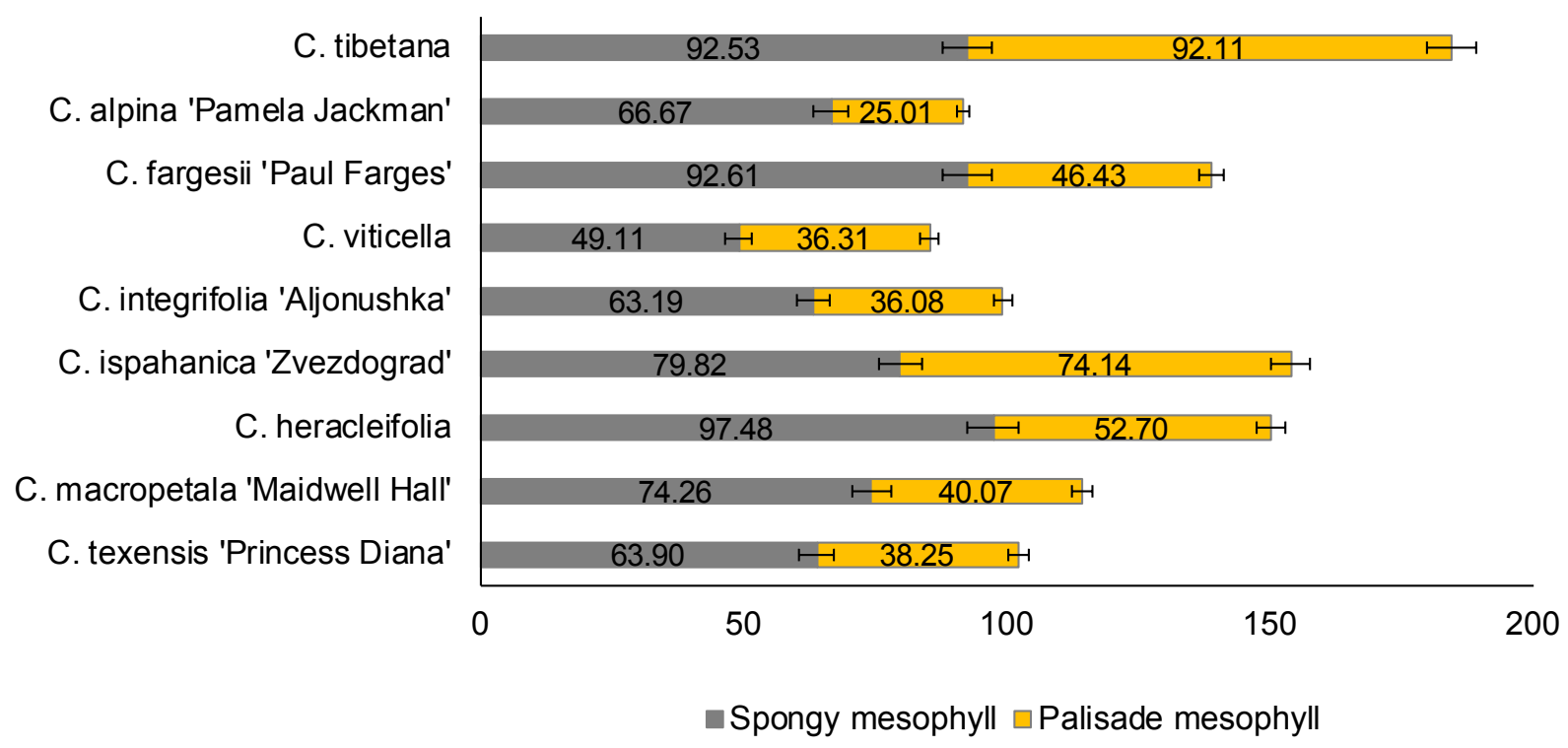

Figure 3. The height of palisade and spongy mesophyll in Clematis leaves.

stomata index of the abaxial leaf surface, and C. heracleifolia - by the low value of this indicator. Close to C. ispahanica 'Zvezdograd', we traced the accumulation of the features associated with the stomata apparatus of the adaxial leaf surface, and thickness of cuticle, palisade mesophyll, and xylem walls. From other studied plants, C. tibetana differed in the thickness of a leaf blade and the height of lower epidermis cells. PCA projections of C. viticella and C. alpina 'Pamela Jackman' appeared distant from other studied taxa on the biplot. Following features were found inherent for $C$. viticella: the lowest values of thickness of the leaf blade, diameter of vascular bundle, diameter of xylem vessels, and average leaf area. The thinnest palisade mesophyll and cuticle were found in C. alpina 'Pamela Jackman'.

The anatomical features of studied clematises were quite heterogeneous, which probably, reflects their ecological variability. In the dendrogram, clematises were grouped into three main clusters. The first one included C. tibetana and C. ispahanica 'Zvezdograd' with the thickest amphistomatic leaves. Cultivars C. alpina 'Pamela Jackman' and C. macropetala 'Maidwell Hall' with hypostomatic leaves and moderate thickness of the leaf blade formed the second cluster. 


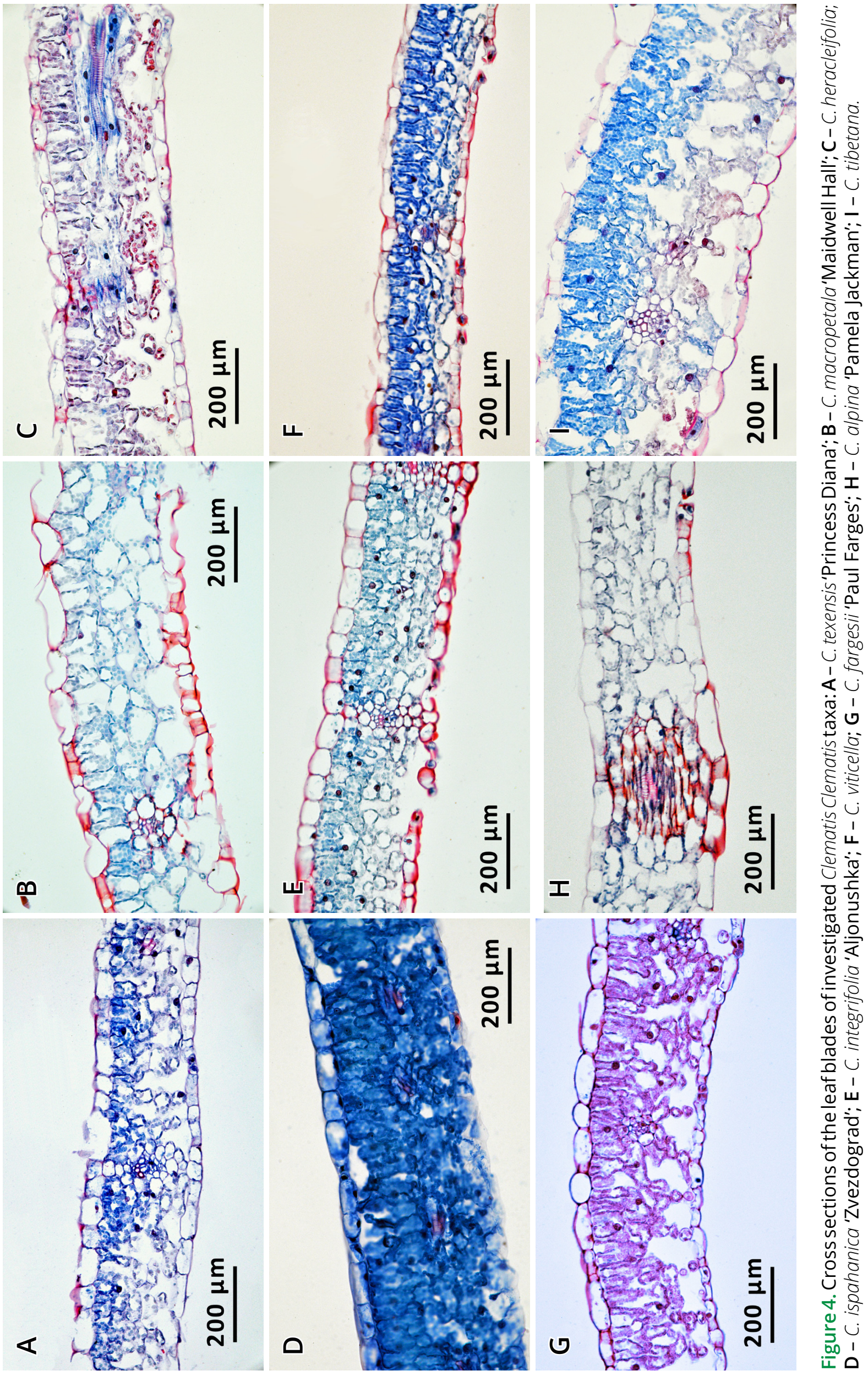



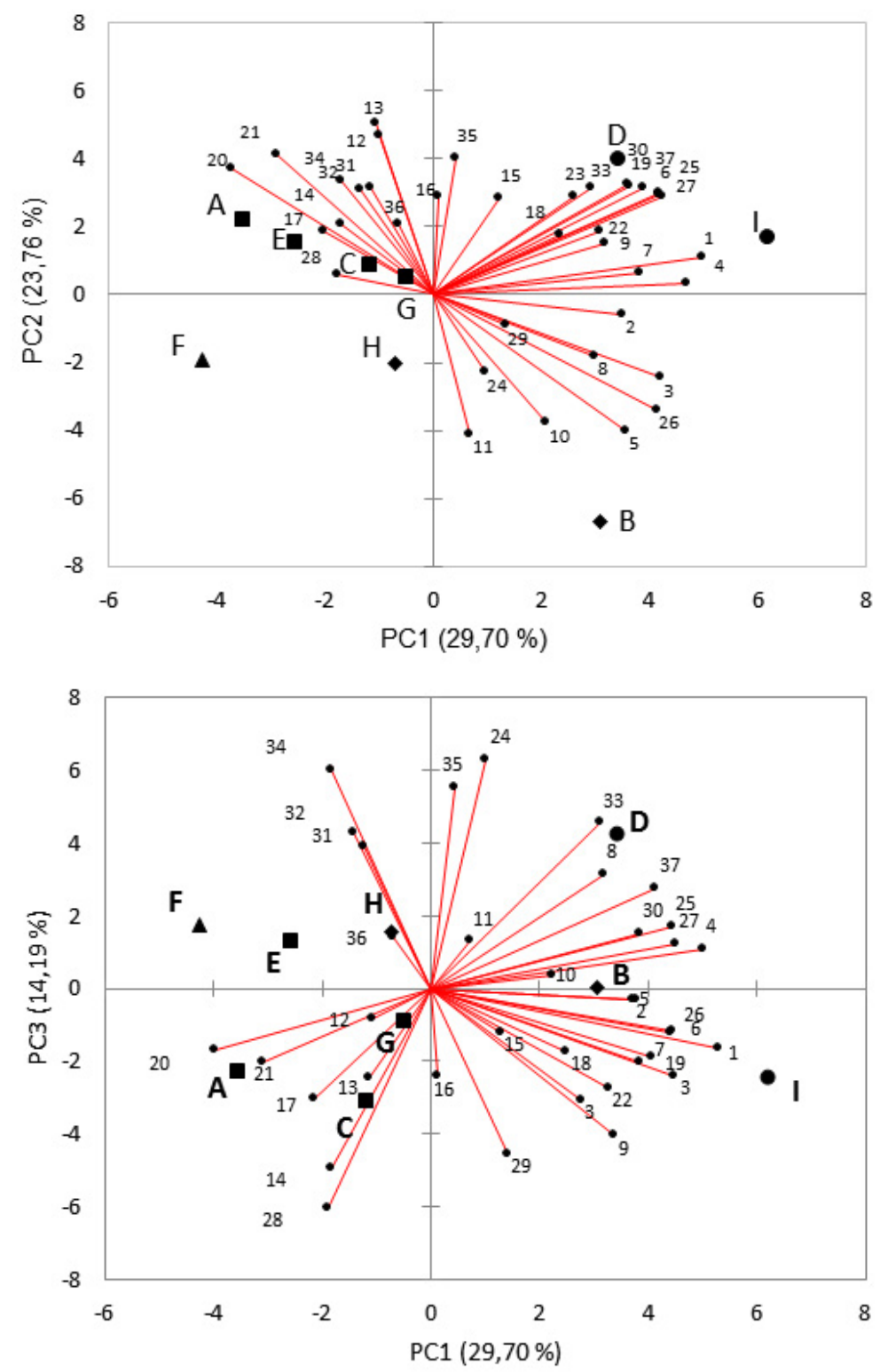

Figure 5. PCA biplot of the studied Clematis taxa and their leaf characters. See Table 2 for the character codes. A - C. texensis 'Princess Diana'; B - C. macropetala 'Maidwell Hall'; C - C. heracleifolia; D - C. ispahanica 'Zvezdograd'; E - C. integrifolia 'Aljonushka'; F - C. viticella; G - C. fargesii 'Paul Farges'; H - C. alpina 'Pamela Jackman'; I - C. tibetana.

The third and the largest cluster included C. viticella, C. fargesii 'Paul Farges', C. integrifolia 'Aljonushka', C. heracleifolia, and C. texensis 'Princess Diana' with hypostomatic leaves thickness of which varied from 109.91 to $184.90 \mu \mathrm{m}$ (Fig. 6).

Despite the difference in origin and habitus, among studied plants, C. heracleifolia and C. texensis 'Princess Diana' were found to be the most similar. The leaves of these plants have the largest area and comparatively thin epidermis, which indicates their mesophytic origin. Another subcluster was formed by the cultivars C. fargesii 'Paul Farges' and C. integrifolia 'Aljonushka'. Such species common for Ukraine as C. vitalba and C. integrifolia were used to create these cultivars. Hence, these cultivars can occupy the niche of parental species in the plantations of deciduous woody plants with low canopy density. In urban landscapes, they can be used for growing in containers, to decorate walls and fences.

The natural range of distribution of C. viticella is located in southern Europe, where it grows in the forest ecotons. 
Table 2. Contribution of selected characters to PCA dispersion. The characters making a significant contribution are indicated in bold.

\begin{tabular}{|c|c|c|c|c|}
\hline \multirow{2}{*}{ No } & \multirow{2}{*}{ Variables } & \multicolumn{3}{|c|}{ Contributions } \\
\hline & & PC1 & $\mathrm{PC} 2$ & PC3 \\
\hline 1 & Leaf blade thickness & 7.846 & 0.386 & 0.759 \\
\hline 2 & Height of the upper epidermis cells & 3.891 & 0.111 & 0.026 \\
\hline 3 & Width of upper epidermis cell & 5.616 & 1.906 & 1.610 \\
\hline 4 & Height of lower epidermis cells & 7.035 & 0.037 & 0.336 \\
\hline 5 & Width of lower epidermis cells & 4.025 & 5.150 & 0.027 \\
\hline 6 & Thickness of palisade mesophyll layer & 5.519 & 2.735 & 0.379 \\
\hline 7 & Height of palisade mesophyll cell & 4.661 & 0.139 & 0.976 \\
\hline 8 & Width of palisade mesophyll cell & 2.848 & 1.029 & 2.787 \\
\hline 9 & Thickness of spongy mesophyll & 3.213 & 0.743 & 4.589 \\
\hline 10 & Height of spongy mesophyll cells & 1.389 & 4.546 & 0.041 \\
\hline 11 & Width of spongy mesophyll cells & 0.149 & 5.354 & 0.471 \\
\hline 12 & Diameter of vascular bundle with sheath cells & 0.315 & 7.050 & 0.190 \\
\hline 13 & Diameter of vascular bundle (transverse) & 0.358 & 8.044 & 1.714 \\
\hline 14 & Diameter of vascular bundle (longitudinal) & 0.940 & 1.378 & 6.781 \\
\hline 15 & Diameter of xylem vessels (transverse) & 0.470 & 2.537 & 0.407 \\
\hline 16 & Diameter of xylem vessels (longitudinal) & 0.004 & 2.639 & 1.643 \\
\hline 17 & Height of phloem & 1.294 & 1.104 & 2.538 \\
\hline 18 & Diameter of bundle sheath cells & 1.755 & 1.007 & 0.836 \\
\hline 19 & Thickness of xylem vessel walls & 4.170 & 3.261 & 1.150 \\
\hline 20 & Thickness of upper epidermis cells outer walls & 4.415 & 4.416 & 0.805 \\
\hline 21 & Thickness of lower epidermis cells outer walls & 2.658 & 5.377 & 1.125 \\
\hline 22 & Thickness of upper cuticle & 3.008 & 1.120 & 2.076 \\
\hline 23 & Thickness of lower cuticle & 2.154 & 2.663 & 2.635 \\
\hline 24 & Width of stomata on the abaxial surface & 0.292 & 1.672 & 11.160 \\
\hline 25 & Width of stomata on the adaxial surface & 5.508 & 2.884 & 0.822 \\
\hline 26 & Length of stomata on the abaxial surface & 5.452 & 3.678 & 0.429 \\
\hline 27 & Length of stomata on the adaxial surface & 5.700 & 2.686 & 0.421 \\
\hline 28 & Leaf area & 1.016 & 0.100 & 10.198 \\
\hline 29 & Leaf perimeter & 0.565 & 0.265 & 5.784 \\
\hline 30 & Leaf mass of defined area & 4.116 & 3.395 & 0.660 \\
\hline 31 & Leaf mass of a defined volume & 0.418 & 3.114 & 4.277 \\
\hline 32 & Number of stomata on the abaxial leaf surface & 0.571 & 3.079 & 5.127 \\
\hline 33 & Number of stomata on the adaxial leaf surface & 2.707 & 3.126 & 5.809 \\
\hline 34 & Number of ordinary epidermal cells on the abaxial leaf surface & 0.935 & 3.531 & 10.122 \\
\hline 35 & Number of ordinary epidermal cells on the adaxial leaf surface & 0.052 & 5.142 & 8.596 \\
\hline 36 & Stomatal index of leaf abaxial surface & 0.129 & 1.398 & 0.543 \\
\hline 37 & Stomatal index of leaf adaxial surface & 4.806 & 3.198 & 2.153 \\
\hline
\end{tabular}




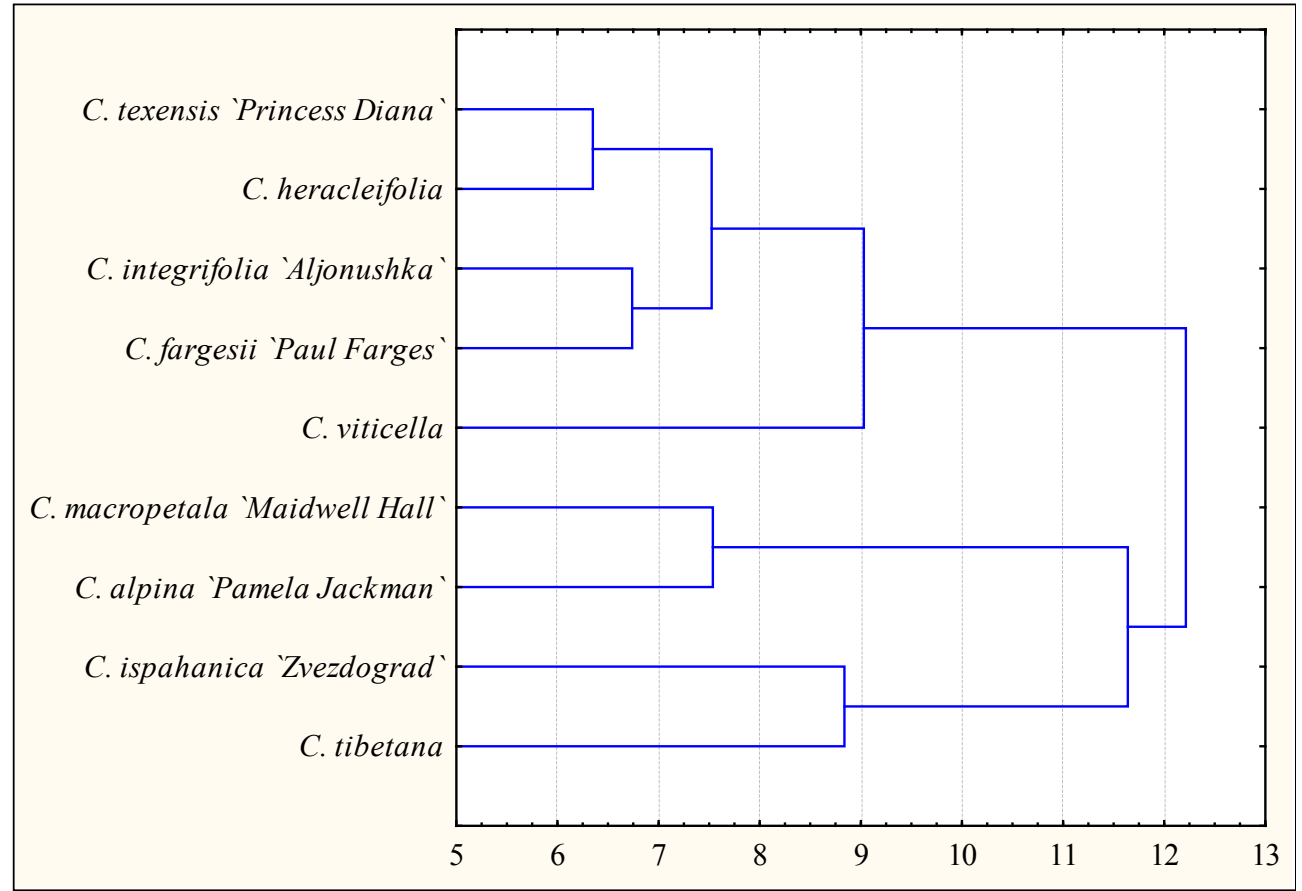

Figure 6. UPGMA clustering of studied clematises basing on morpho-anatomical parameters.

This explains the shade tolerance peculiarities in the structure of its leaves. Therefore, this species, as a bright summer accent, fits the woody plantations with low canopy density.

Cultivars C. alpina 'Pamela Jackman' and C. macropetala 'Maidwell Hall' are traditionally attributed to the Atragene group, which combines clematises from the Northern Hemisphere forests. These plants grow in partial shade, and bloom in spring during rapid fluctuations of the daily temperature under a sparse canopy of the trees in windy forest biocenoses. Small leaves and their dissection can be a result of adaptation of these plants to mentioned growing conditions. Hence, the best places for their growth in the city are on the edges and along the paths in the parks and squares composed by deciduous trees. In such conditions they will get enough light during the flowering period and enough shade during the hot summer time.

Stony steppe slopes with high insolation are the natural habitats of $C$. tibetana and C. ispahanica. Clematis tibetana and C. ispahanica Boiss. 'Zvezdograd' have the following leaf structure features: amphistomatic leaves, high palisade coefficient, and relatively significant total leaf blade thickness. Such features are crucial for the plants growing on mountain slopes with high insolation and fluctuations in daily temperatures. The small area of leaves allows these plants to avoid damage by ground particles during the winds. While the relatively thick cuticle reduces transpiration and refracts sunlight. These traits are genetically determined and persist even in plants growing in urban areas. Therefore, C. tibetana and C. ispahanica 'Zvezdograd' are appropriate for growing on windy, rocky mounds.

\section{Conclusions}

Adaptive features of the studied clematises are different. Complex analysis of their leaf morpho-anatomical structure allowed assessing the ecological preferences of these plants. In particular, among the main characters of heliophilous clematises were determined amphistomatic leaves, a high palisade coefficient, and a considerably thick cuticle. The small diameter of vascular bundles and the thin cuticle layer are signs of shade-tolerant clematises. While the mesophytic clematises combine a thin cuticle layer and large size of stomata, mesophilic and epidermal cells. Small-celled leaf tissues, in general, indicate drought-resistant clematises. 


\section{References}

Addinsoft. (2017). XLSTAT 2017.1. https://help.xlstat. $\mathrm{com} / \mathrm{s} /$ article/principal-component-analysispca-in-excel?language=en_US

Ahmad, K. S., Hameed, M., Fatima, S., Ashraf, M., Ahmad, F., Naseer, M., \& Akhtar, N. (2016). Morpho-anatomical and physiological adaptations to high altitude in some Aveneae grasses from Neelum Valley, Western Himalayan Kashmir. Acta Physiologiae Plantarum, 38(4), 93. https://doi.org/10.1007/s11738-016-2114-x

Araujo, F. F., Santos, M. N., Costa, L. C., Moreira, K. F., Araujo, M. N., Martinez, P. A., \& Finger, F. L. (2019). Changes on potato leaf metabolism and anatomy induced by plant growth regulators. Journal of Agricultural Science, 11(7), 139-147. https://doi.org/10.5539/jas. v11n7p139

Arimy, N. Q., Nisyawati, \& Metusala, D. (2017). Comparison of leaf anatomy on some Nepenthes spp. (Nepenthaceae) from highland and lowland habitat in Indonesia. AlP Conference Proceedings, 1862, Article 030111. https://doi. org/10.1063/1.4991215

Bååth, E., \& Anderson, T.-H. (2003). Comparison of soil fungal/bacterial ratios in a $\mathrm{pH}$ gradient using physiological and PLFA-based techniques. Soil Biology and Biochemistry, 35(7), 955-963. https:// doi.org/10.1016/S0038-0717(03)00154-8

Beskaravaynaya, M. A. (1998). Clematises - vines of the future. Kvarta. (In Russian)

Box, G. E. P., Hunter, J. S., \& Hunter, W. J. (2005). Statistics for experimenters: design, innovation and discovery. Wiley.

Buisson, D., \& Lee, D. W. (1993). The developmental responses of papaya leaves to simulated canopy shade. American Journal of Botany, 80, 947-952. https://doi.org/10.1002/j.1537-2197.1993. tb15316.x

Clematis on the Web (2021, May 28). Clematis A-Z. http://www.clematisontheweb.org/newclemalphasearch.cfm

Everitt, B. S., Landau, S., Leese, M., \& Stahl, D. (2011). Cluster analysis. 5th ed. Wiley. https://doi. org/10.1002/9780470977811

Evert, R. F. (2005). Esau's plant anatomy. Meristems, cells, and tissues of the plant body - their structure, function, and development. Wiley. https://doi. org/10.1093/aob/mcm015

Furst, G. G. (1979). Methods of anatomical and histochemical study of plant tissues. Nauka. (In Russian)

Hanba, Y. T., Kogami, H., \& Terashima, I. (2002). The effect of growth irradiance on leaf anatomy and photosynthesis in Acer species differing in light demand. Plant, Cell \& Environment, 25(8), 1021-1030. https://doi.org/10.1046/j.13653040.2002.00881.x

Isnard, S., Rowe, N., \& Speck, T. (2003). Growth habit and mechanical architecture of the sand dune-adapted climber Clematis flamula var. maritima L. Annals of Botany, 91(4), 407-417. https://doi.org/10.1093/aob/mcg044

Javed, A., Ahmad, M., Zafar, M., Sultana, S., Khan, M. A., \& Arshad, M. (2012). Palynoanatomical studies of Clematis L. (Ranunculaceae) from Poonch Valley Ajk, Pakistan. The Journal of Animal \& Plant Sciences, 22(4), 1173-1176.

Jinghua, S., \& Liangqian, L. (2003). Leaf epidermal feature in Clematis (Ranunculaceae) with reference to its sistematic significance. Acta Botanica Sinica, 45(3), 257-268.

Kogami, H., Hanba, Y. T., Kibe, T., Terashima, I., \& Masuzawa, T. (2001). $\mathrm{CO}_{2}$ transfer conductance, leaf structure and carbon isotope composition of Polygonum cuspidatum leaves from low and high altitudes. Plant, Cell \& Environment, 24(5), 529-538. https://doi.org/10.1046/j.13653040.2001.00696.x

Moon, A.-R., Han, J.-E., Lee, B.-Y., Park, J.-M., \& Jang, C.-G. (2013). An unrecorded species of genus Clematis (Ranunculaceae) from Korea. Journal of Asia-Pacific Biodiversity, 6(4), 415-418. https://doi.org/10.7229/jkn.2013.6.4.00415

Ornellas, T., Heiden, G., Nunes de Luna, B., \& Franca Barros, C. (2019). Comparative leaf anatomy of Baccharis (Asteraceae) from highaltitude grasslands in Brazil: taxonomic and ecological implications. Botany, 97(11), 615-626. https://doi.org/10.1139/cjb-2019-0035

Pashkevych, N. A. (2014). Anatomical and morphological adaptation of the leaves of Eragrostis minor Host (Poaceae) in different ecological conditions. Modern Phytomorphology, 6, 309-314. https://doi.org/10.5281/ zenodo.160786

Rijekstynja, V. E., \& Rijekstynysh, I. R. (1990). Clematises. Agropromizdat. (In Russian)

Sneddon, B. V. (1975). A new clematis from NorthWest Nelson, New Zealand. New Zealand Journal of Botany, 13(3), 557-565. https://doi.org/10.108 0/0028825X.1975.10430342

Systat Software. (2010). SigmaPlot 12: user's guide. Systat Software.

Takhtajan, A. L. (1978). The floristic regions of the World. Nauka. (In Russian)

Tamura, M. (1993). Ranunculaceae. In The families and genera of vascular plants. Vol. 2. Flowering plants. Dicotyledons (pp. 563-583). Springer. 
Vachnovskaya, N. G. (2007). Recommendations for the propagation, cultivation and use of large flower clematises in Kyiv. Phytosociocentr. (In Ukrainian)

Zanão Júnior, L. A., Alvarez Venegas, V. H., Fontres, R. L. F., Carvalho-Zanão, M. P., DiasPereira, J., Maranho, L. T. \& Pereira, N. (2017). Leaf anatomy and gas exchange of ornamental sunflower in response to silicon application. Bioscience Journal, 33(4), 833-842. https://doi. org/10.14393/BJ-v33n4a2017-36559
Zarinkamar, F., Tajik, S., \& Soleimanpour, S. (2011). Effects of altitude on anatomy and concentration of crocin, picrocrocin and safranal in Crocus sativus L. Australian Journal of Crop Science, 5(7), 831-838.

Zhang, H.-X., Zhang, M.-L., \& Sanderson, S. C. (2013). Retreating or standing: responses of forest species and steppe species to climate change in arid Eastern Central Asia. PLOS One, 8(4), Article e61954. https://doi.org/10.1371/ journal.pone.0061954

\section{Морфологічні ознаки листків ломиносів як відображення їх екологічних особливостей}

Ірина Ковалишин ${ }^{1, *}$, Андрій Пінчук ${ }^{2}$, Артур Ліханов ${ }^{2}$

\footnotetext{
1 Інститут фізіології рослин і генетики Національної академії наук України, вул. Васильківська, 31/17, Київ, 03022, Україна; * Iryna_В_Kovalyshyn@ukr.net

2 Національний університет біоресурсів і природокористування України, вул. Героїв Оборони, 15, Київ, 03041, Україна
}

Визначення кількісних показників морфологічних і анатомічних ознак листкових пластинок здійснювали для дев'яти видів і сортів ломиносів (Clematis alpina 'Pamela Jackman', C. macropetala 'Maidwell Hall', C. integrifolia 'Aljonushka', C. ispahanica 'Zvezdograd', C. fargesii 'Paul Farges', C. texensis 'Princess Diana', C. tibetana, C. viticella та C. heracleifolia).

Серед досліджених ломиносів були присутні рослини з гіпостоматичними (C. viticella, C. fargesii 'Paul Farges', C. heracleifolia, C. texensis 'Princess Diana', C. macropetala 'Maidwell Hall', C. alpina 'Pamela Jackman') та амфістоматичними листками (C. ispahanica 'Zvezdograd' і C. tibetana). А також рослини з гіпостоматичні листками, які мали поодинокі продихи на адаксіальній поверхні листків (C. integrifolia 'Aljonushka'). Коефіцієнт палісадності листків коливався від 27,3% (C. alpina 'Pamela Jackman') до 49,9 \% (C. tibetana). Листки досліджених рослин також суттєво відрізнялися за площею, зокрема у C. integrifolia 'Aljonushka' площа листкової поверхні майже у десять разів перевищувала таку у C. heracleifolia.

У результаті кластерного аналізу, перший кластер був сформований C. tibetana та C. ispahanica 'Zvezdograd'. Ці рослини, здатні виживати в умовах різкого перепаду температур і вітряної погоди на відкритих кам'янистих ділянках. До другого кластеру увійшли C. alpina 'Pamela Jackman' та C. macropetala 'Maidwell Hall' - рослини, які цвітуть навесні, в період значної зміни добових температур. Порівняно невелика площа листків цих рослин може вказувати на адаптацію шляхом зменшення транспіраційної площі та парусності. Третій кластер об'єднав мезофітні рослини, які відрізняються від решти більшою загальною площею листків. Однак, до третього кластеру також увійшов культивар C. integrifolia 'Aljonushka', який відрізняється найменшою площею листкової пластинки, але має подібну морфо-анатомічну будову. 